\title{
PERANAN REPRESENTASI BERBANTUAN SOFTWARE MAPLE PADA PEMBELAJARAN MATA KULIAH KALKULUS
}

\author{
Arie Candra Panjaitan \\ Amik MEdicom \\ ariecandra.or@gmail.com
}

\begin{abstract}
Computers are essential tools for teaching, learning, and doing mathematics. Computers can visualize or represent mathematical ideas, organize and analyze data, and calculate effectively and accurately. Computers can help students conduct investigations through representations in various fields of mathematics such as geometry, calculus, statistics, algebra, measurements, and numbers. This paper discusses the role of Maple assisted representation in calculus learning. Representation is very supportive in increasing students' understanding of mathematical relations and concepts. There are three main functions of representation, namely complementing, constraining, and constructing. Complementing function is to complete the process and complete the information. The constraining function is to help students experience difficulties in a representation. The constructing function is to support constructing a deeper understanding of a concept. Students can get a deeper understanding if difficulties with only one representation. Maple software is a facility that is very supportive in making representations in learning mathematics as in calculus learning. By using Maple we can do numerical and symbolic calculations and perform graphical representations well. Maple can also effectively determine limits, derivatives, integrals, and a series of other functions and capabilities. With this Maple software capability, we can use it to improve students' understanding of calculus courses.
\end{abstract}

Keywords: Representation, Computers, Maple, Calculus

\begin{abstract}
Abstrak. Komputer adalah alat yang esensial untuk pengajaran, pembelajaran, dan doing matematik. Komputer dapat memvisualisasikan atau merepresentasikan ide matematika, mengorganisir dan menganalisis data, dan menghitung secara efektif dan akurat. Komputer dapat membantu siswa dalam melakukan investigasi melalui representasi pada berbagai bidang matematika seperti geometri, kalkulus, statistik, aljabar, pengukuran, dan bilangan. Tulisan ini membahas peranan representasi berbantuan Maple dalam pembelajaran kalkulus. Representasi sangat mendukung dalam peningkatan pemahaman siswa terhadap relasi dan konsep matematika. Terdapat tiga fungsi utama dari representasi yaitu complementing, constraining, dan constructing. Fungsi complementing yaitu melengkapi proses dan melengkapi informasi. Fungsi constraining yaitu membantu siswa bila mengalami kesulitan dalam suatu representasi. Fungsi constructing yaitu untuk mendukung mengkonstruksi pengertian yang lebih dalam terhadap suatu konsep. Siswa dapat memperoleh pengertian yang lebih dalam jika kesulitan dengan hanya satu representasi. Software Maple merupakan fasilitas yang sangat mendukung dalam melakukan representasi dalam pembelajaran matematika seperti pada pembelajaran kalkulus. Dengan menggunakan Maple kita dapat melakukan perhitungan numerik dan simbolik serta melakukan representasi grafik dengan baik. Maple secara efektif juga dapat menentukan limit, turunan, integral, dan deret suatu fungsi serta kemampuan lainnya. Dengan kemampuan software Maple ini maka kita dapat memanfaatkannya untuk meningkatkan pemahaman mahasiswa dalam mata kuliah kalkulus.
\end{abstract}

Kata Kunci: Representasi, Komputer, Maple, Kalkulus

\section{PENDAHULUAN}

Representasi merupakan salah satu kunci ketrampilan komunikasi matematik. Pembelajaran maternatika yang menekankan pada ketrampilan dan kemampuan representasi, pada dasarnya melatih ketrampilan siswa dalam komunikasi matematik (NCTM, 2000). Sebagian besar komunikasi matematik berkaitan dengan ketrampilan 
representasi. Dengan demikian, representasi matematik merupakan suatu kemampuan yang harus dikuasai oleh siswa/mahasiswa.

Salah satu alat (tool) untuk representasi adalah komputer, dalam hal ini adalah software Maple. Software Maple ini biasa digunakan dalam perkuliahan matematika, fisika, dan teknik. Maple mempunyai kemampuan untuk manipulasi simbol, mengkreasi grafik, menampilkan materi, melakukan perhitungan, mengkreasi program, dan lain-lain di sekolah dan perguruan tinggi. Kemudian Maple, sangat mendukung dalam melakukan pengembangan eksplorasi matematika melalui representasi simbolik, numerik, dan grafik (Beckmann, 1988; Ostebee \& Zorn, 1990).

Dalam makalah ini akan dibahas tentang pemanfaatan kemampuan software Maple dalam menampilkan berbagai representasi sehingga dapat meningkatkan pemahaman mahasiswa dalam mata kuliah kalkulus.

\section{PEMBAHASAN}

\section{Multiple Representasi}

NCTM ( 2000) merekomendasikan ada lima kompetensi standar yang utama yaitu kemampuan pemecahan Masalah (Problem Solving), kemampuan Komunikasi (Communication), kemampuan Koneksi (Connection), kemampuan Penalaran (Reasoning), dan Representasi (Representation). Pada awalnya standar-standar yang direkomendasikan di dalam NCTM 1989 hanya terdiri dari empat kompetensi dasar yaitu Pemecahan Masalah, Komunikasi, Koneksi, dan Penalaran; sedangkan Representasi masih dipandang sebagai bagian dari Komunikasi matematika. Namun, karena disadari bahwa representasi matematika merupakan suatu hal yang selalu muncul ketika orang mempelajari matematika pada semua tingkatan/level pendidikan, maka dipandang bahwa representasi merupakan suatu komponen yang layak mendapat perhatian serius. Dengan demikian representasi matematika perlu mendapat penekanan dan dimunculkan dalam proses belajar mengajar matematika di sekolah. Oleh karena itu di dalam pembelajaran matematika, kemampuan mengungkapkan gagasan/ide matematik dan merepresentasikan gagasan/ide matematik dapat merupakan suatu hal yang harus dilalui oleh setiap orang yang sedang belajar matematika.

Makna representasi bisa berbeda-beda dalam konteks yang berbeda. Secara umum, representasi adalah suatu konfigurasi yang dapat menyajikan suatu benda dalam suatu cara (Goldin , 2002). Selanjutnya, Palmer (Kaput \& Goldin, 2004) mengemukakan bahwa representasi adalah suatu konfigurasi atau sejenisnya, yang berkorespondensi dengan sesuatu, mewakili, melambangkan atau menyajikan sesuatu. Sebagai contoh, $f(x)=x^{2}$ merupakan suatu representasi dari fungsi tertentu, demikian pula grafiknya pada bidang kartesius, ataupun suatu tabel.

Dalam psikologi representasi berarti proses membuat model hal-hal yang nyata dalam dunia sebenarnya ke dalam konsep atau simbol abstrak. Jo Nassen (Hwang et.al, 2007) juga menginterpretasikan model mental sebagai representasi mental yang kompleks yang tersusun atas aneka jenis komponen mental yang meliputi metaforis, visual-spatial, dan pengetahuan struktural.

Dalam psikologi matematika, representasi bermakna deskripsi hubungan antara objek dengan simbol. Lesh Post dan Behr (Hwang et.al, 2007) menunjukkan lima lapisan luar representasi yang digunakan dalam pendidikan matematika yang meliputi representasi objek dunia nyata, representasi ganda, representasi simbol aritmetika, representasi bahasa lisan dan gambar atau representasi grafik. Di antara representasi itu, tiga yang terakhir lebih abstrak dan merupakan tingkat representasi yang lebih tinggi untuk memecahkan masalah matematika. 
1. Kemampuan representasi bahasa yaitu kemampuan menerjemahkan ciri dan hubungan yang diobservasi di dalam masalah matematika ke dalam representasi verbal atau vokal.

2. Kemampuan representasi gambar atau grafik yaitu kemampuan menerjemahkan masalah matematik ke dalam gambar atau representasi grafik.

3. Kemampuan representasi simbol aritmatika yaitu kemampuan menerjemahkan masalah matematika ke dalam representasi formula aritmatika.

Representasi matematika dapat digolongkan menjadi dua, yaitu representasi eksternal dan representasi internal. Representasi internal dari seseorang sulit untuk diamati secara langsung karena merupakan aktivitas mental dari seseorang di dalam otaknya (minds-on). Tetapi representasi internal dari seseorang itu dapat disimpulkan atau diduga berdasarkan representasi eksternalnya dalam berbagai kondisi, misalnya melalui pengungkapannya melalui kata-kata (lisan), melalui tulisan berupa simbol, gambar, grafik, tabel, ataupun melalui alat peraga (hands-on). Dengan kata lain, terjadi hubungan timbal balik antara representasi internal dan eksternal dari seseorang disaat berhadapan dengan sesuatu yang dihadapinya.

Hiebert (Pape, Tchoshanov, 2001) mengusulkan beberapa komponen yang esensial yang dapat menfasilitasi pencapaian kompetensi dalam menggunakan simbol matematika yaitu (1) siswa harus menghubungkan simbol dengan objek yang ditampilkan (2) siswa harus mengembangkan prosedur manipulasi simbol atau algoritma yang melaksanakan penggunaan simbol tersebut (3) prosedur harus menjadi rutin (4) simbol dan aturan tersebut harus dirinci dan digunakan sebagai rujukan untuk membangun sistem yang lebih abstrak.

Model pembelajaran Bruner (Pape, Tchoshanov, 2001) didasarkan pada tiga level yang berkaitan dengan representasi yaitu: enactive (manipulasi benda konkrit), iconic (gambar dan grafik), dan symbolic (numeral). Fokus utama dari implementasi pendekatan ini dalam pembelajaran matematika adalah peningkatan berpikir representasional siswa dalam konteks: (1) alternatif cara untuk melakukan eksplorasi siswa dalam penyelidikan dan penalaran matematika (2) keterlibatan siswa dalam variasi aktivitas hands-on dan minds-on (modeling, drawing, imagining, mapping, dll) dalam proses menginterpretasikan dan mengkomunikasikan ide matematika (3) konstruksi dan ko-konstruksi siswa (dalam interaksi sosial) dalam multiple representasi non-standar dari pemecahan masalah dan teknik bukti (4) pemahaman siswa tentang hubungan harmonis antara bentuk berbeda dari multiple representasi pengetahuan matematika.

Terdapat empat implikasi dari penggunaan multipel representasi dalam pembelajaran di kelas yaitu (1) siswa hendaknya diberi kesempatan menggunakan kedua representasi yaitu eksternal dan internal melalui aktivitas sosial yang melibatkan bervariasi representasi eksternal (2) representasi secara inherent menjadi aktivitas social. (3) supaya anak menjadi ahli matematika yang kompeten, guru harus menggunakan teknik yang bervariasi (analitik dan geometri) (4) representasi harus dipikirkan sebgai alat untuk berpikir, menjelaskan, dan membuktikan. Guru dan siswa harus mengembangkan aturan kelas yang menfasilitasi penjelasan dan pembuktian dan menggunakan representasi dalam mendukung argument (Pape, Tchoshanov, 2001).

Aspinwall dan Shaw (Ainsworth, 2004) menetapkan siswa akan mengkonstruk pemahaman yang lebih kaya bila mereka mengeksplorasi dan mensintesis hubungan diantara representasi grafik dan analitik. Hughes-Hallett (1991), Hughes-Hallett et al (2002), (Ainsworth, 2004), menyatakan bahwa representasi grafik, visualisasi, dan berpikir visual (visual thinking) adalah bagian dari pemahaman matematik dan perannya sangat dibutuhkan dalam pemahaman konsep dasar kalkulus.

Menurut Ainsworth (2004) terdapat tiga fungsi utama dari multiple eksternal representasi (MERs) yaitu complementing, constraining, dan constructing. Fungsi complementing yaitu melengkapi proses, melengkapi informasi. Fungsi constraining yaitu 
pembantu siswa bila mengalami kesulitan dalam suatu representasi. Jika siswa mengalami kesulitan dengan satu representasi maka siswa dapat menggunakan representasi lain yang lebih familiar. Dapat juga menampilkan suatu ide dengan berbagai representasi secara bersamaan. Fungsi constructing yaitu untuk mendukung konstruk pengertian yang lebih dalam. Siswa dapat memperoleh pengertian yang lebih dalam jika kesulitan dengan hanya satu representasi. Siswa dapat meningkatkan pemahaman yang lebih dalam terhadap suatu konsep dengan cara translasi representasi sebuah konsep kepada jenis representasi lain. Menurut Even (Gagatsis \& Elia, 2003), Kemampuan untuk mengidentifikasi dan menampilkan konsep yang sama dalam representasi yang berbeda dan perpindahan dari satu representasi ke representasi lain akan memungkinkan siswa untuk melihat hubungan yang kaya dan mengembangkan pengertian yang dalam dari konsep tersebut.

Zimmermann (Haciomeroglu, 2007) menyatakan bahwa peran dari berpikir visual (visual thinking) adalah sangat mendasar dalam pemahaman kalkulus, sehingga sulit untuk membayangkan kesuksesan pengajaran kalkulus tanpa menekankan pada visualisasi dari topic yang dipelajari. Aspek yang mendasar dari berpikir visual dalam kalkulus adalah memahami turunan dari titik pandang grafiknya. Siswa seharusnya dapat menggambar grafik turunan, turunan kedua atau anti turunan dari sebuah fungsi jika diberikan grafik fungsi asalnya. Dalam aplikasi kalkulus, representasi visual dari masalah yang ditampilkan secara verbal adalah sangat esensial. Sangat sulit untuk dipahami sebagian masalah nyata dalam kalkulus tanpa representasi visual yang memadai. Siswa seharusnya mempunyai pemahaman yang memadai tentang representasi visual dan kemampuan untuk membuat hubungan antara representasi analitik dan grafik. Hughes-Hallett (Haciomeroglu, 2007), menganjurkan keseimbangan antara representasi grafik, numeric, dan analitik. Keseimbangan diperlukan karena akan melihat hubungan antara berbagai pendekatan yang meningkatkan pemahaman.

Arcavi (Haciomeroglu, 2007), mengidentifikasi tiga peran penting dari visualisasi: Visualisasi dapat berguna sebagai (a) mendukung dan ilustrasi hasil secara aljabar (b) sebuah kemungkinan cara untuk memecahkan konflik antara solusi aljabar yang benar dan intuisi yang tidak benar (c) sebuah cara untuk membantu kita memulihkan pondasi konsep yang dengan mudah terlewatkan oleh solusi formal.

\section{Representasi dengan Software Maple}

Crowley (2001), menyatakan penggunaan teknologi memungkinkan siswa untuk mengakses multiple representasi dari konsep fungsi. Doerr \& Zangor, (2000), kalkulator grafik atau komputer dapat diperlakukan sebagai mesin penghasil representasi. Pengguna dapat mengubah bentuk simbolik fungsi ke dalam representasi grafik dan tabel dengan cepat dan mudah. Bila penggunaannya bersama dengan kurikulum yang menyoroti hubungan antar representasi tersebut, kalkulator grafik dapat menjadi alat yang ampuh mengembangkan pemahaman tentang fungsi.

Salah satu software yang dapat digunakan adalah Maple. Software Maple adalah salah satu jenis dari computer algebra system (CAS). Maple dirancang oleh grup riset di Waterloo University, Canada. Di dalam Maple terdapat lebih dari 3.500 fungsi yang terintegrasi, dan mampu melakukan berbagai representasi (simbolik, tabel, dan grafik). Di antara keistimewaan yang dimiliki oleh Maple adalah: 1) jenis operasi interaktif, 2) mampu mendefinisikan perhitungan matematik, 3) tidak membutuhkan pengalaman awal dengan peralatan komputer, 4) mudah untuk belajar dan system penggunaan, 5) responsivepengguna.

Maple dapat melakukan perhitungan numerik dan simbolik secara efektif seperti menentukan: turunan fungsi, integral numerik dan analitik, limit fungsi, penjumlahan dan perkalian, transformasi Laplace, transformasi-z diskrit, transformasi Fourier, dan bekerja 
pada fungsi kontinu sebagian. Selanjutnya Maple juga dapat menentukan solusi dari deret simbolik, sistem persamaan linear dan non-linear, sistem persamaan diferensial, persamaan transenden, dan sistem pertidaksamaan.

Dalam kalkulus kita dapat menggunakan representasi grafik untuk menjelaskan konsep limit dan turunan. Berikut akan diberikan beberapa ilustrasi penggunaan Maple dalam perkuliahan kalkulus.

Misalnya dalam menunjukkan bahwa nilai $\lim _{x \rightarrow 0} x \sin \left(\frac{1}{x}\right)=0$. Kita dapat membuat grafik fungsinya untuk $x$ mendekati nol yaitu pada interval [$0.000000001,0.000000001$ ], seperti gambar berikut.

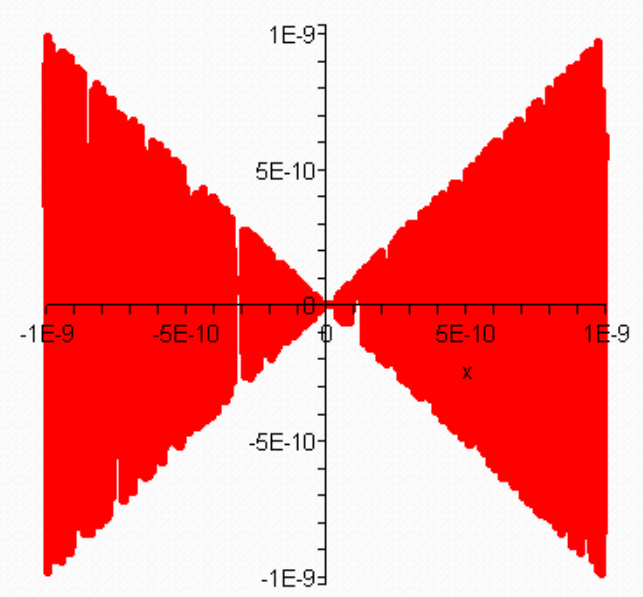

Gambar 1. $P \operatorname{lot}(x * \sin (1 / x), x=-0.000000001 \ldots 0.000000001)$

Dari sini kita dapat menduga bahwa nilai limitnya adalah 0, karena dari grafik kelihatan bahwa dia mendekati 0 untuk $x$ menuju 0 . Kemudian dengan cara yang sama kita dapat juga mengilustrasikan bahwa $\lim _{x \rightarrow 0} \sin \left(\frac{1}{x}\right)$ tidak ada. Dari gambar di bawah terlihat bahwa nilai $f(x)=\sin (1 / x)$ selalu "bergoyang" di sekitar $x=0$ dan tidak menuju suatu bilangan. Dengan demikian dapat kita katakan bahwa limitnya tidak untuk $x$ menuju 0 .

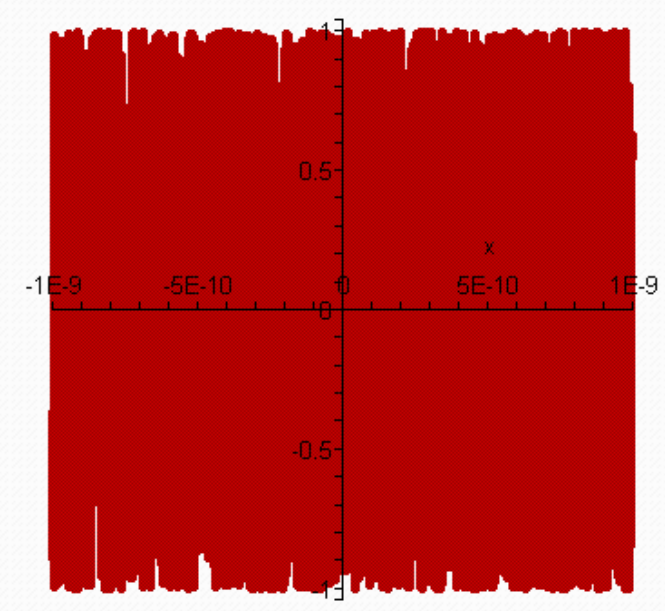

Gambar 2. $P$ lot $(\sin (1 / x), x=-0.000000001 \ldots 0.000000001)$ 
Maple juga dapat kita gunakan untuk menunjukkan kelinearan suatu kurva pada interval yang kecil. Dalam kalkulus sering digunakan pendekatan bahwa suatu kurva dapat dianggap sebuah garis lurus jika intervalnya sangat kecil. Misalnya grafik $\mathrm{f}(\mathrm{x})=\sin \mathrm{x}$ pada interval $[0,2 \pi]$, grafiknya adalah seperti gambar berikut.

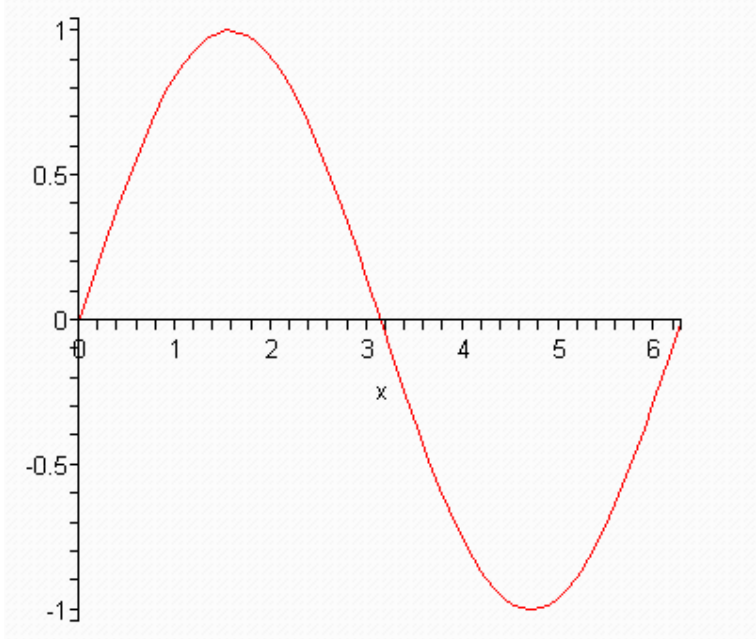

Gambar 3. $P \operatorname{lot}(\sin (x), x=0 \ldots 2 * P i)$

Dengan mempersempit intervalnya maka kita dapat tunjukkan bahwa grafiknya berupa garis lurus. Misalnya pada interval $[\pi / 1001, \pi / 1000]$, maka grafiknya adalah sebuah garis lurus seperti gambar berikut.

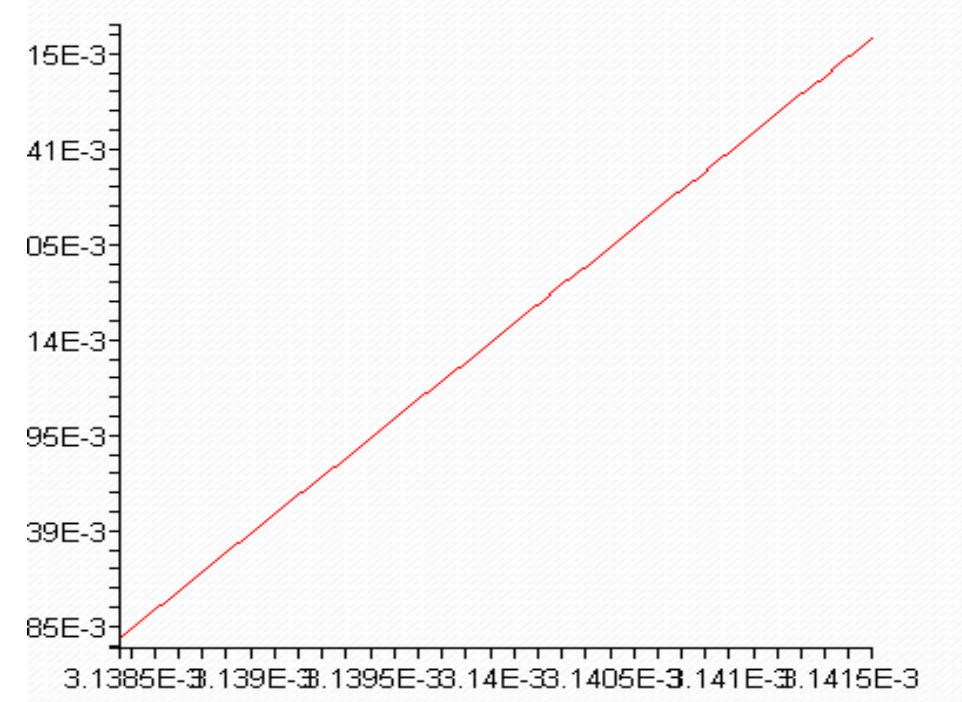

Gambar 4. $P \operatorname{lot}(\sin (x), x=P i / 1001$. . Pi/1000)

\section{KESIMPULAN}

Representasi memegang peranan penting dalam meningkatkan pemahaman konsep matematika siswa/mahasiswa. Representasi memberikan keuntungan yang unik bagi siswa yang sedang mempelajari ide baru yang kompleks. Komputer merupakan alat yang dapat digunakan untuk menampilkan berbagai representasi. Pada saat ini computer sudah bukan barang yang asing lagi di dunia pendidikan. Untuk itu sudah selayaknya kita memanfaatkan computer dalam proses pembelajaran. 


\section{DAFTAR PUSTAKA}

Ainsworth, S., Van Labeke, N. (2004). Multiple forms of dynamic representation. Learning and Instruction, 14(3)

Beckmann, C. E. (1988). Effect of computer graphics use on student understanding of calculus concepts. (Doctoral dissertation, Western Michigan University, 1988). Dissertation Abstracts International, 50, 1974B.

Gagatsis, A, Elia, I \& Andreou, S. (2003). "Representations and Mathematics Learning: Functions and Number Line", Euclidean $\gamma, 59,5$ - 34

Goldin, G. A.(2002). Representation in Mathematical Learning and Problem Solving. In. L.D. English (Ed). International Research in Mathematics Education IRME, 223. New Jessey: Lawrence Erlbaum Associates.

Haciomeroglu, E. S. (2007). Calculus students' Understanding of Derivative Graphs: Problem of Representations in Calculus, Dissertation: The Florida State University of Education.

Hwang. et.al (2007). Multiple representation Skills and Creativity Effects on Mathematical ProblemSolving using a Multimedia Whiteboard System. Journal Educational Technology \& Society. 10(2). 191-212.

Kapput, J. J., Goldin, G.A. (2004). A joint Perspectiveon the Idea of Representationin Learning and Doing Mathematics. [Online]. Tersedia: http://www. simlac.usmassad. edu.

National Council of Teacher Mathematics. (2000). Principles and Standards for Schools Mathematics. USA: Reston. V.A.

Ostebee, A. \& Zorn, P. (1990). St. Olaf College: Viewing calculus from graphical and numerical perspectives. In T. W. Tucker (Ed.), Priming the calculus pump: Innovations and resources. pp. 199-222. Washington, DC: The Mathematical Association of America.

Pape, S. J., Tchoshanov, M. A. (2001). The Role of Representation(s) in Developing Mathematical Understanding, Theory into Practice, 40(2), 118 - 127. 